\title{
Sportcivil társaságok - megközelítések és tények
}

\section{Sport Civic Society - Approaches and Facts}

\author{
Szabados Gy. N. ${ }^{1}$, Helmeczi A. ${ }^{2}$, BÁcsné B. É. ${ }^{3}$, Fenyves V.4 , BÁcs Z5., DAJNOKi K. ${ }^{6}$ \\ ${ }^{1}$ Debreceni Egyetem, Gazdaságtudományi Kar, Szervezés és Kommunikáció Tanszék, \\ szabados.gyorgy@econ.unideb.hu \\ 2Debreceni Egyetem, Gazdaságtudományi Kar, Gazdasági Jog Tanszék, helmeczi.andras@econ.unideb.hu \\ ${ }^{3}$ Debreceni Egyetem, Gazdaságtudományi Kar, Sportgazdasági- és Menedzsment Intézet, \\ bacsne.baba.eva@econ.unideb.hu \\ ${ }^{4}$ Debreceni Egyetem Gazdaságtudományi Kar, Kontrolling Tanszék, fenyves.veronika@econ.unideb.hu \\ ${ }^{5}$ Debreceni Egyetem Gazdaságtudományi Kar, Számviteli Tanszék, bacs.zoltan@econ.unideb.hu \\ ${ }^{6}$ Debreceni Egyetem, Gazdaságtudományi Kar, Emberi Erőforrás Menedzsment Tanszék, dajno- \\ ki.krisztina@econ.unideb.hu
}

\section{A publikáció elkészítését a EFOP-3.6.2-16-2017-00003 számú projekt támogatta. A projekt az Európai Unió támogatásával, az Európai Szociális Alap társfinanszírozásával valósult meg.}

Absztrakt. Magyarországon az 1989-es rendszerváltást követően kezdődött meg a civil szektor erösödése, több törvényi átmenetet követöen mindenekelött a jelenleg is hatályos 2011. éviCLXXV. törvény (rövid nevén civil törvény, Civiltv. vagy Ectv.) szabályozza a szektor múködését, kiegészülve további törvényi háttérrel. Az új szabályozás lényeges eleme egy, az addigiaktól alapvetően eltérô szervezeti forma, az ún. civil társaság megjelenése, mely szokatlan szervezeti forma nemzetközi szinten is. A KSH 2019. év végén megjelent, a hazai nonprofitok statisztikai áttekintését lehetôvé tévố adatbázis gyakorlatilag semmiféle információt nem tartalmaz az új szervezeti forma múködési sajátosságaira, adataira vonatkozóan, sőt, igazából alig lehet valamit tudni róluk, mely okkal kelti fel a kutató érdeklődését a téma és a szervezeti forma iránt. A lehetséges szekunder adatokon túl egy, a közelmúltban befejezett sportcivil szervezeti kutatás primer adatbázisa ugyanakkor tartalmaz, ha alacsony elemszámban is, olyan alapvető adatokat, mely kiinduló pontot jelenthet a sporttal összefüggésbe hozható civil társaságok egyes sajátosságainak feltárására.

Kulcsszavak: nonprofit, sport, civil társaság, Központi Statisztikai Hivatal

Abstract. After the change of regime in Hungary in 1989, the domestic civic sphere started to improve, and after numerous change in the legal regulation, currently the Act on Civic Organizations (Act 174/2011.) rules the operation of the sector before all, supplemented by additional legal background. The vital component of the new regulation is possibility of the appearance of the novel organizational form, the civic society, which is quite odd even considering the past and even on international level. The database enabling the statistical overview of the domestic nonprofits publish the end of 2019 provides no information on the data and operational features for this organizational form, 
which provides a thorough reason for the researcher to be interested in the topic and the organizations. Through the possible secondary data, a primary database of a lately done sports civic organization related research includes such basic data (even its sample height is small), which may be considered as a starting point at the examination of the specifications of the sports related civic societies.

Keywords: nonprofits, sports, civic society, Central Statistical Office

\section{Bevezetés}

Nem kétséges, hogy a magyarországi szervezeti formák, típusok között a civil szervezetek iránti érdeklődés valamiféle ambivalens képet mutat jelenleg, annak függvényében, hogy azt milyen tudományterület oldaláról igyekszünk megközelíteni. A legfelkapottabb érdeklődést jelenleg is a politikatudomány mutatja, ahol egyrészt a civil társadalom, és az azzal összefüggésbe hozható civil szervezetek integrált részét képezik az egységes poltikatudományi megközelítésnek [9], [8], [16].

A szociológia itthon két elfogadott általános alapmunkája [3], [5] szintén szervesen tartalmaz politikatudományi megközelítéseket, különösen az állam és a kormányzat vonatkozásában. Maga a menedzsment tudománya úgy tűnik, hogy csak megkésve fedezte fel a téma iránt az érdeklődést, a '80 as évek nemzetközi menedzsment irodalma [17], [6] csak humán jellegű, de nem civil vonatkozásokat tartalmaz. Az újabb irodalmak is [7], [4] sem szentelnek dedikált fejezeteket a nonprofit szférának, a téma vonatkozásai keveredve, elsősorban a társadalmi felelősségvállaláshoz kötődve jelennek meg. Itt kell megjegyezni, hogy a menedzsment irodalom régóta fennálló hiányosságának tekinthető mind hazai, mind nemzetközi szinten az egyes áttekintő, összehasonlító jellegű szervezeti klasszifikációja, ugyanis ezen a téren erősen úgy tűnik, hogy a tudományosság felülbírálta a praktikumot, és egyértelműen a vállalkozásokra, azok innovációjára törekvés dominál. Ami kimarad, az a szervezetek nemzetközi szinten történő értelmezése, hiszen például ilyen szinten léteznek a részvénytársaságok, egyes további vállalkozási formák is, nonprofitok, stb. Ésszerű lenne tehát végre beilleszteni a kormányzati, forprofit (vállalkozási) és nem-kormányzati (nonprofit) szektor globális áttekintését, ugyanis ez utóbbi szektor, indikátorai (így gazdasági, humán, érintettség, stb.) és globalizálódásuk miatt (azaz szerte a világon a demokrácia kiteljesedésével), egyre jelentősebb szerepet kapnak szinte valamennyi téren.

Az egyesülési jogról, a közhasznú jogállásról, valamint a civil szervezetek múködéséről és támogatásáról szóló 2011. évi CLXXV. törvény [1] sokak szerint mérföldkő a szektor működésének átláthatóvá tételében. Ezzel alakult át az NCA, ezzel jelenik meg a közhasznúság újszerű megközelítése, bizonyos beszámolási kötelezettségek egyértelműsítése, de a fő momentuma a szervezeti formák letisztulása. A törvényt követő érdekességként megemlíthető, hogy erősen úgy tűnik, hogy a KSH ennyi év után sem tudja ezt a megközelítést teljesen átvenni, pl. 2017-ben még NCA-t említ [12], de sok más tekintetben is érezhető a megközelítési különbség: a KSH nonprofit kategóriái [13]: klasszikus civilek (egyesületek, alapítványok), érdekképviseletek (köztestületek, munkaadói, munkavállalói és szakmai szervezetek) és nonprofit vállalkozások (nonprofit gazdasági társaság, közalapítvány). A civil törvény szerinti szervezetek: egyesület, alapítvány, civil társaság. Nyilván van különbség nonprofit és civil szervezet között, az eltérő fogalmak ugyanakkor eltérő megközelítéseket is tartalmaznak. A témánk szempontjából érdekes újszerű civil szervezeti forma, a civil társaság a KSH klasszifikációjában, 
adatbázisában nem szerepel, ezt a törvényszéki kereső (www.birosag.hu) sem nevesíti. Mégis, a civil törvény kiemelt figyelmet fordított e szervezeti típus elérhetőségére, azaz kell, hogy legyen jelentősége akkor is, ha azt sem a KSH, sem a törvényszék nem igazán tudja mindeddig egészen jól befogadni, ugyanakkor ennek oka is van.

A Nonprofit Tudástár [15] szerint ez a szervezeti forma nem is igényel „bírósági vagy hatósági bejegyzést, regisztrációt... a tagok társasági szerződésben jelölik meg a célokat, az együttműködés formáját, a társaság szervezetét és képviseletét." Egy másik forrás [10]ennél már pontosabban és részletesebben fogalmaz, amikor a már eddig leírtakan túl azt is ismerteti, hogy ez a szervezet esetében a polgári jogi társaságra vonatkozó szabályokat (Ptk. 6:498-513. §) kell alkalmazni, az Ectv. 5/A.§-ban foglalt eltérésekkel [2]. Ez azt jelenti, hogy ez a szervezeti típus - a civil törvény 5/A.§ alapján gyakorlatilag egy speciális polgári jogi társaság, ami nem jogi személyiség (azaz a tagoktól nem elkülönült és nyilvántartott entitás, hanem a tagok közötti szerződéses kapcsolat), nem végezhet gazdasági-vállalkozási tevékenységet, ezért nincs adószáma, nem állíthat ki számlát sem, viszont a speciális (civil) jelleg miatt vagyoni hozzájárulás nélkül is létrehozható. Egy utolsó, számunkra lényeges momentum részletei egy, a jegyzo.hu-n közzétett cikkből derül ki [14]: „Megjegyzendő ugyanakkor, hogy az Ectv. értelmében - többek között - a támogatások, a gazdálkodás, a törvényességi ellenőrzés, bírósági nyilvántartás, beszámolási rend, a Nemzeti Együttmúködési Alap terhére nyújtott támogatások tekintetében a civil társaságot nem kell civil szervezet alatt érteni. Ez azt jelenti, hogy ezen társaságok és az államháztartás alrendszerei között támogatási szerződés vagy támogatói okirat alapján létesített költségvetési támogatási jogviszony nem keletkeztethetö". Ez viszont különösen lényeges, hiszen az eddigiek alapján az látható, hogy önálló bevétele nem lehet, és állami támogatást sem kaphat. Ez ugyanis azért érdekes, mert (1) a KSH legutolsó statisztikái szerint a sport cél szerinti tevékenység alapján rögzített 9693 sport célú nonprofitból 758 alapítvány, 27 közalapítvány, 8723 egyesület, 8 köztestület, 177 nonprofit gazdasági társaság adja a sport célú nonprofitokat, és ha a bírósági nyilvántartásban nem is, de a KSH statisztikáiban ez a szervezeti forma lassan meg kellene hogy jelenjen (hiszen ez is civil szervezet lenne), (2) a 2018-as adatok szerinti bevételek a sport cél szerinti tevékenységü nonprofitoknál 288 024,1 millió Ft, melynek 70\%-a $(69,99)$ támogatás, és domináns az állami, ugyanis a támogatások 87,02\%-a állami támogatás [12]. Azaz a sportszervezetek támogatása meghatározott, és érdekes a kérdés, hogy amennyiben egy civil társaság erre a sportcélra jön létre, de sem állami támogatásban, sem gazdasági-vállalkozási tevékenység bevételeiben nem részesülhet, úgy miként tudja önmagát fenntartani. Ha nincs regisztrálva, akkor beszámolási kötelezettsége sem a NAV, sem az államháztartási egyéb rendszerek, sem a törvényszék felé nincs, így a szokásos civil szervezeti sajátosságok, dimenziók közül ezek nem lehetnek lényegesek, ugyanakkor humán erőforrások, az aktivitás és a társadalmi beágyazottság/érintettség kérdései mind-mind olyan fejezetek, ahol joggal merülhet fel a kutató és a szakma kíváncsisága is a 2011 óta létező szervezetei forma egyes ilyen sajátosságai iránt, különösen akkor, ha erre vonatkozóan empirikus felvételezési eredményekre is lehet támaszkodni. 


\section{Anyag és módszer}

A vizsgálat anyagát egyértelműen a viszonylag új civil szervezeti forma a civil társaság adja. Annak érdekében, hogy a szervezeti forma sajátosságairól legalább valamennyire alapvető képet kaphassunk, azt egy empirikus kutatás tette lehetővé. 2019. nyarán egy, a hazai sportcivil szervezetek különféle sajátosságait feltárni kívánó kérdőíves kutatás alapjait fektettük le azzal, hogy eddigi tapasztalatainkra, munkáinkra alapozva, a KSH és a törvényszék kategóriáit is szem előtt tartva, egy terjedelmes, 94 változóból összeállított mérőeszközt szerkesztettünk. Ennek főbb dimenziói a Szervezeti alapadatok, a Szakmai tevékenységi kérdések, a Dokumentációs kérdések, a Humán erőforrás kérdések, a Gazdasági kérdések és az Érintettségi kérdések. A változók többségében alacsony mérési szintűek, nominális vagy ordinális jellegűek, a kérdések egy jelentős része Likert-skála alapján mért. A mintavétel tekintetében az alapadatok bázisa az Optende rendszerben fellelhető 12120 hazai sporttal foglalkozó nonprofit sportszervezet (látható tehát a KSH és az Optende különbsége), a válaszadók a szervezetek képviselői/döntéshozói. A felmérés 1000 db-os mintával készült, települési ill. megyei szinten reprezentatív. Tekintettel arra, hogy múködési formáját tekintve igen kevés az $1000 \mathrm{db}$-os mintában az a szervezet, amely alapítványi formában múködik, a minta alapvetően egyesületi jellegü, de található benne 14 alapítvány, és a mi vizsgálatunk szempontjából érdekes 9 civil társaság is. Tisztában vagyunk a minta alacsony elemszámával (sőt a válaszok esetén sem mindegyik egyértelmű és némelyik hiányos), ugyanakkor egyelőre ennél jobb adatbázisról jelenleg nincs tudomásunk. A megkérdezés módja telefonos és internetes elérhetőségre alapozott. Az eredmények rögzítése excel és spss formátumban történt, a releváns adatok kiértékelése kapcsán pedig leíró statisztikák közül átlag, gyakoriság és kereszttábla elemzésre vállalkozunk, az SPSS 23 segítségével.

\section{Eredmények}

Vélhetően egy ilyen kis minta esetén előfordulhat erős területi koncetráció, ezt igazolja a felvételezés, mely szerint a vizsgált 9 civil társaság közül 6 Pest megyében székel (sőt ezek mindegyikének székhelye a főváros), egy csongrádi (ennek székhelye Szeged), 1 győr-mosonsoproni és 1 borsodi, ez utóbbiak székhelye egy-egy falu. A szervezet működési feltételeinek milyenségét Likert-skála alapján (1-5-ig) 8 válaszadó ítélte meg, ezek összességében 3 és 5 között mozogtak, az átlaguk 4,12 (std.dev. 0,99).

\subsection{A szervezeti aktivitás megítélése}

A mindössze 8 érvényes válasz alapján úgy tűnik, hogy a szervezetek szakmai aktivitása önbevallás alapján inkább közepesnél valamivel jobb, erre utal, hogy mindössze 1 szerint igen aktív, az átlag 3,75 (std. dev. 0,70). A civil szervezeteknél szokásos aktivitás kategóriák, így az (1) Alapvető működési, igazgatási tevékenység (azaz pl. könyvelés, beszámolás, menedzsment), (2) Cél szerinti állandó szakmai tevékenység (azaz pl. folyamatosan szociális, környezetvédelmi vagy kulturális 
tevékenység folytatása, jelen esetben állandó sporttevékenység, pl. edzés, verseny) (3) Cél szerinti programszerű, nem állandó tevékenységeket (akár egy támogatáshoz fűződő egyedi esemény megszervezése, pl. részvétel falunapon, vagy egyedi esemény megszervezése) vizsgálata alapján úgy tûnik, hogy elsősorban az állandó tevékenységek intenzításának megítélése nyomatékosabb, azaz az átlagokat (Alapvető...3,5, Állandó szakmai....4,37, Programszerű nem állandó 3,87) tekintve az állandó szakmai tevékenységek tekinthetőek a szervezet legaktívabb tevékenységeinek (1. ábra). Láthatóan ez, azaz a cél szerinti állandó tevékenység ezeknek a szervezeteknek az erőssége.

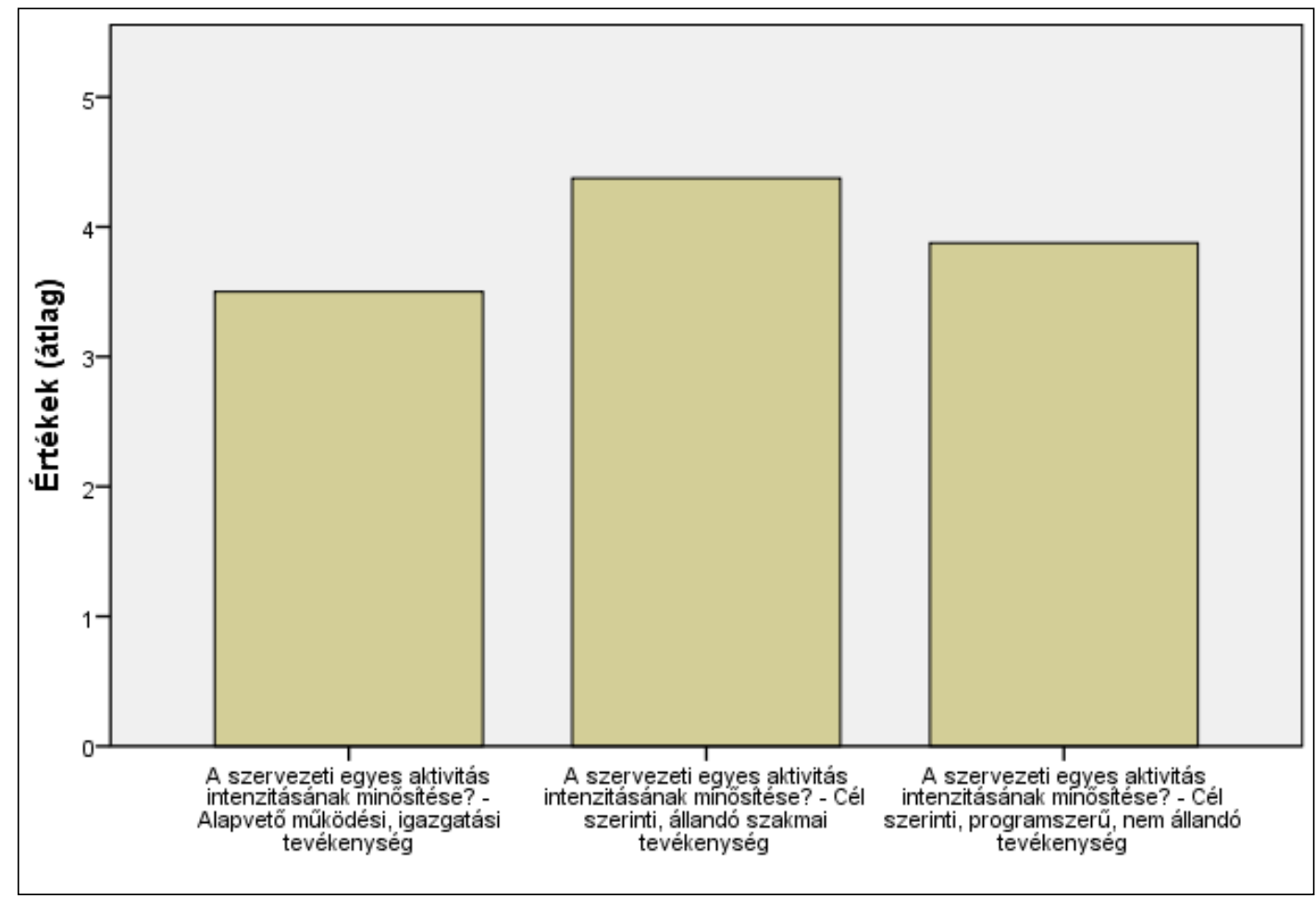

1. ábra. A civil társaságok egyes aktivitás kategóriáinak megítélése Forrás: A szerzők saját szerkesztése (2020)

A szervezetek saját megítélése alapján mindössze negyedük (2 szervezet) utazik versenysportban, a szervezetek többsége (6) szabadidősport profilú. A szervezetek javarésze monoprofilú (6 szervezet), azaz sporton kívül nincs további tevékenységük, míg kettőnek van. A sporton kívüli egyéb tevékenységek egyébként a törvényszéki cél szerinti tevékenység lista alapján kerültek meghatározásra, és elsősorban kulturális, szabadidő-hobbi, oktatás, szociális tevékenység kerültek megemlítésre. A szakmai tevékenységek megítélésére vonatkozó kérdések kapcsán ebben a fejezetben egyes, a szervezetek múködésére vonatkozó itemek/állítások is szerepeltek, melyeket noha korábban Likert-skála alapján szerettük volna felvételezni, ám a felvételezések kapcsán a visszajelzések miatt kerültek módosításra bináris formára (Igen/Nem). A válaszokból megtudhattuk, hogy:

- a szervezetek sporteredményei az elvártaknak csaknem teljesen megfelel (9-ből 8 Igen) 
- az egyéb, nem sport jellegű tevékenységek megítélése már nem ilyen optimista (9-ből csupán 5 Igen)

- a szervezetek sporttevékenységével kapcsolatosan változásokra lenne szükség (4 Igen/5 Nem)

- a szervezetek 2/3-ának van publikációs nyilvánossága (pl. szerepelt már helyi lapban)

- majd az összes (9-ből 8) szervezet nyilvánosságát önálló honlap vagy közösségi média profil támogatja

- és a szervezetek szakmai kapcsolatrendszere is összességében aktív, hiszen 9-ből 7 szervezet képviseltette magát szakmai konferencián, vagy tart kapcsolatot szakmai szövetséggel.

\subsection{A humán erőforrások megítélése}

A vizsgált civil társaságok humán erőforrás intenzitása összességében valamivel a jó alatt marad, az átlag 3,75, a szervezetek fele szerint az aktivitás csupán közepes. A foglalkoztatási viszonyok megítélése a szabályozás fényében viszonylag egyszerűnek tűnik, mivel a szervezetek teljes vagy részmunkaidős foglalkoztatottakról egyáltalán nem adtak számot, viszont az önkéntesek szerepe itt jelentősebb: 2-11-ig terjedt az önkéntesek száma a szervezeteknél, és a szervezetek fele esetében 6, másik fele esetében 10 önkéntes segíti a munkavégzést. A humán erőforrással kapcsolatos itemek/kijelentő állítások bináris megítélésével kapcsolatos válaszokból kiderült, hogy:

- a szervezetek humán erőforrás aktivitása többségében az elvártak szerint alakul (7 Igen/2 Nem)

- a szervezet tevékenységében közreműködők összességében leterheltek (7 Igen/ 2 Nem)

- mindössze egy szervezet jelentkezett be a közérdekű önkéntes foglalkoztatásának lehetőségére

- a szervezetek munkakultúrája egyöntetűen kiváló

- a közremúködői állomány tekintetében a fluktuáció a szervezetek kétharmada szerint jelentéktelen, 3 szervezeti válaszadó ezt ettől eltérően látta

\subsection{Az érintettség kérdésének megítélése}

Az érintettség, Kovách [11] munkáját adaptálva, a szervezetek és a társadalom kapcsolatát jelenti, azaz milyen összefüggés van a civil szervezetek és a környező társadalmi közeg között. A kutatás ezen része összefüggést kívánt feltárni a vizsgált szervezetek társadalmi hatása és az adott településen működő más civil szervezetek társadalmi hatása között. Az egyes eredmények azt mutatják, hogy a vizsgált civil társaságok társadalmi hatása elmarad a település egyéb civil szervezeteinek hatásától (2. ábra): 


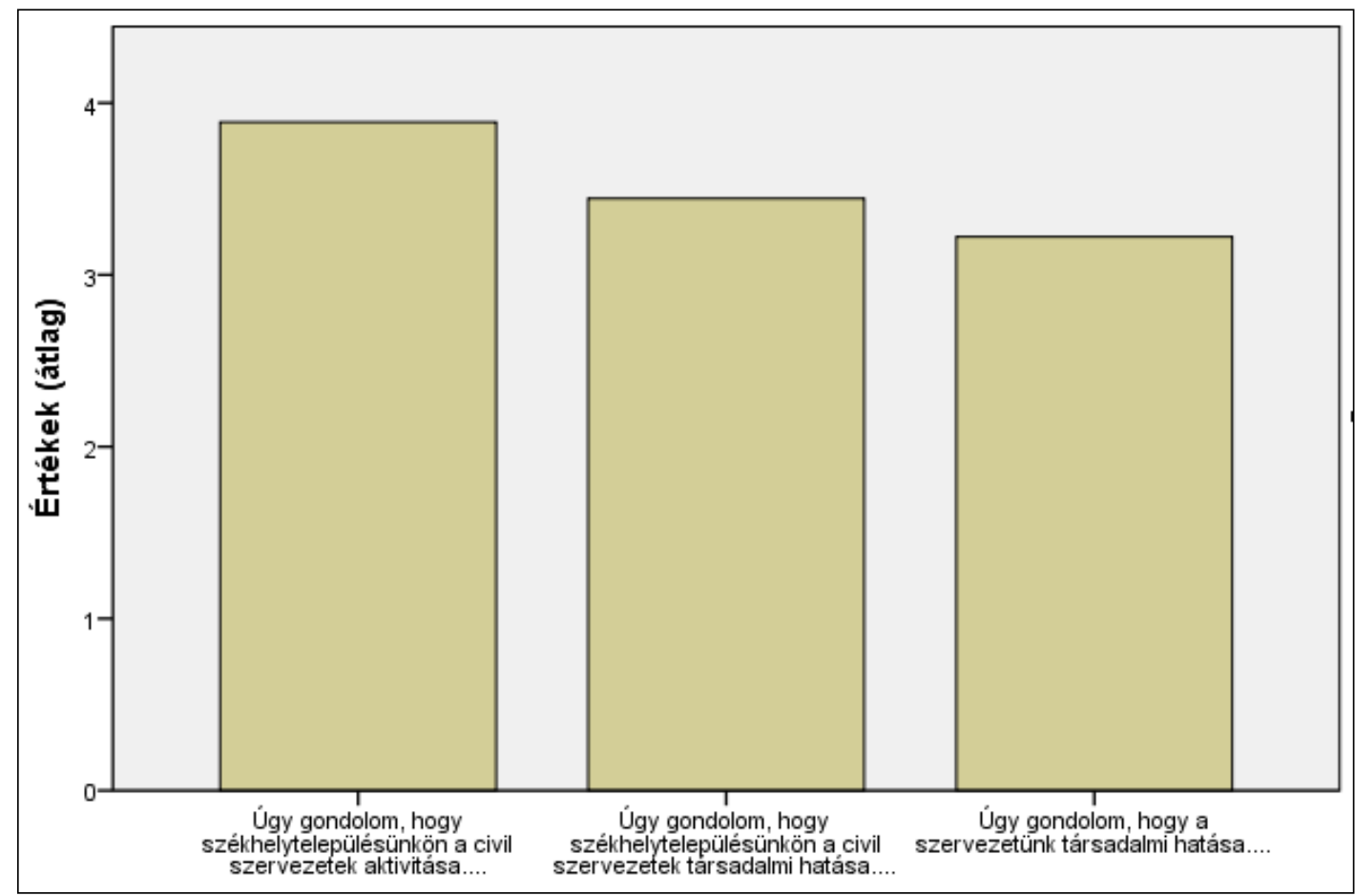

2. ábra: A civil társaságok társadalmi hatása a székhelytelepülésen

Forrás: A szerzők saját szerkesztése (2020)

Az eredmények arra utalnak, hogy a székhelytelepüléseken a civil szervezetek aktivitása alapvetően sem igen magas (az előző adat ismeretében a civil társaságok szakmai aktivitása még ezt sem éri el a 3,75-ös átlaggal), ennél pedig gyengébb a társadalmi hatásuk, a civil társaságok esetében pedig a többi civil szervezethez képest is elmarad a társadalmi hatás $(3,44$ vs 3,22$)$. A közepest épp elérő társadalmi hatás jogosan veti fel az új szervezeti formával kapcsolatos kételyeket (tiszteletben tartva a minta határait): miért is jó a civil társaság, ha nem tud olyan hatással bírni, mint az egyéb civil szervezetek a sport terén? A további eredmények arra utalnak, hogy ez az érintettség a szervezetek egy jelentős részében (50\%) igen limitált, mivel csak a tagsággal, és egy jól meghatározott körrel van kapcsolatban. A szervezetek és az érintetti kör kapcsolata dominánsan közvetlen (9-ből 8 válaszadó nyilatkozott így). Azt, hogy ez a hatás mennyire materiális, jelzi az utolsó kérdés, ahol a válaszadók úgy látták, hogy a szervezetek hatása többségében (9-ből 6 szervezet) anyagilag kisebb mértékben csoportszinten is érezhető, nagyobb mértékben pedig egyéni szinten is.

\section{Következtetések}

A civil társaságok megjelenése az új civil törvénnyel hozható összefüggésbe, az irodalmazás alapján látható, hogy a szokásos civil szervezeti kategóriáktól eltérően komoly korlátok mentén működnek. A kisminta nyilvánvalóan jelent korlátokat, azonban vizsgálatunk tudomásunk szerint az első ilyen kezdeményezés az újszerű szervezeti forma sajátosságainak 
feltárásával kapcsolatosan, ez tehát mindenképpen egy feltáró jellegű kutatásnak tekinthető. A szervezeti aktivitás összességében közepesnél jobb megítélésén túl úgy tûnik, hogy ezeknek a szervezeteknek a többi tevékenységükhöz képest az alapvető célszerinti tevékenység az erősségük, és mivel ezek sportszervezetek, vélhetően jobbak a sport terén, mint az adminisztrációban, menedzselésben vagy épp alkalmi programok, tevékenységek szervezésében. A humán háttér megítélésnek átlaga hasonló a szakmai aktivitáshoz, és a szervezeti típus sajátosságainak megfelelően az önkéntesség jellemző, és noha a HR aktivitás összességben a szervezetek többsége szerint az elvártak szerint alakul, és a munkakultúra kiváló, mégis vannak jelek a HR jellegű problémáklétéről: ilyen a leterheltség vagy épp az azzal akár összefüggésben is lehető fluktuáció. Az érintettség kapcsán úgy tűnik, hogy ezek a szervezetek nem tudnak a többi civil szervezethez hasonló módon beágyazódni és a helyi társadalmak szintjén úgy teljesíteni, mint a többi civil szervezeti típus: társadalmi hatásuk elmarad a többi szervezettől, és a közepes közeli megítélés jogosan vethet fel kételyeket ezekkel a szervezetekkel kapcsolatosan.A tanulmánynak a kutatást követően is fennálló kérdése, hogy mi is az előnye ennek a formának, ha nincs mögötte annyi forrás, nem olyan intenzívek, a HR korlátokkal küzd és a szervezetek társadalmi hatása is elmarad a többi civil szervezeti formától a vizsgált terület, a sport terén? Erre további kutatások hozhatják meg a választ, elsősorban a jogi szabályozás hatásosságának és a közösséghez való viszonynak az elemzésével

\section{Hivatkozások}

[1] 2011. évi CLXXV. törvény az egyesülési jogról, a közhasznú jogállásról, valamint a civil szervezetek működéséről és támogatásáról

[2] 2013. évi V. törvény a Polgári törvénykönyvről

[3] Andorka R. (2006): Bevezetés a szociológiába. Osiris Kiadó, Budapest, 783.

[4] Bodday, D. (2014): Management. An Introduction. Pearson, Harlow, 720.

[5] Giddens, A. (2008): Szociológia. Osiris Kiadó, Budapest, 819.

[6] Griffin, R. (1984): Management. Houghton Mifflin Company, Boston

[7] Griffin, R. (2013): Management. 11.ed. South Western Cengage Learning, Mason, 686

[8] Gyurgyák J. (2004): Mi a politika? Bevezetés a politika világába. Osiris Kiadó, Budapest, 436.

[9] Haskó K. - Hülvely I. (2003.) Bevezetés a politikatudományba. Osiris Kiadó, Budapest, 246.

[10] Kós Károly Közösségi Központ (2020): Civil társaság létrehozásának főbb ismérvei. https://koskarolykozpont.hu/wp-content/uploads/2018/05/Civil-t\%C3\%A1rsas\%C3\%A1g1\%C3\%A9trehoz\%C3\%A1s\%C3\%A1nak-f\%C5\%91bb-ism\%C3\%A9rvei.pdf (letöltés ideje: 2020.02.14.) 
[11] Kovách I. (2012): A vidék az ezredfordulón. A jelenkori magyar vidéki társadalom szerkezeti és hatalmi változásai. Argumentum Kiadó-MTA Társadalomtudományi Kutatóközpont (Szociológiai Intézet), Budapest, 42-46.p.

[12] KSH (2018): A nonprofit szektor legfontosabb jellemzői 2017-ben. Kapcsolódó adatok. http://www.ksh.hu/apps/shop.kiadvany?p_kiadvany_id=1041504\&p_temakor_kod=KSH\&p_lang =HU (letöltés ideje: 2020. 02.11.).

[13] KSH (2019): A nonprofit szektor legfontosabb jellemzői 2018-ban. https://www.ksh.hu/docs/hun/xftp/stattukor/nonprofit/nonprofit18.pdf (letöltés ideje: 2020. 02.11.)

[14] Mitták T. (2012): Változások a civil szervezetek támogatásában és működésében, az önkormányzati rendeletalkotás nehézségei. jegyzo.hu/cikkek.XIV.évf. 1. lapszám. https://jegyzo.hu/valtozasok-a-civil-szervezetek-tamogatasaban-es-mukodeseben-azonkormanyzati-rendeletalkotas-nehezsegei/ (letöltés ideje?: 2020.02.14.)

[15] Nonprofit.hu: Nonprofit tudástár. https://www.nonprofit.hu/tudastar/hogyan-kellletrehozni-civil-tarsasagot (letöltés ideje: 2020. 02.14.)

[16] Pupek E. - Vass L. (2009): A politikatudomány alapjai. BKF Fenntartói Kft, Budapest, 180. [17] Torgersen, P.E. - Weinstock, I.T. (1972): Management. An Integrated Approach. PrenticaHall, New Jersey, 498. 